fungerer også som grundige indføringer i den klassiske fænomenologis teoritradition. Bogens forfattere har et udmærket blik for de centrale pointer i de fænomenologiske teorier og formår også at formidle disse på en sådan måde, at de uindviede har en chance for at kunne forstå de til tider komplekse teorier.

En nærmere diskussion af hvert kapitels særkende er ikke muligt her. Til gengæld skal bidragyderne roses for deres bestræbelser på at levere anvendelige teoretiske og metodiske værktøjer ud fra en bred vifte af tematiske tilgange. Med udgangspunkt i hver sit teoretiske og empiriske felt lykkes det bidragyderne at vise spændvidden i den fænomenologiske praksis.

Indirekte er bogen en opfordring til de studerende om ikke at tage den moderne antropologiske og sociologiske fænomenologi for gode varer. I stedet kan man læse de moderne fænomenologer i kortene ved selv at vende tilbage til de klassikere, som de bygger deres teorier på. Nye og anderledes teori- og metodeudviklinger behøver nødvendigvis ikke altid at tage udgangspunkt i de nyeste teorier, for „det nye“ kan også findes i ,det gamle“.

Philip Martinussen

Cand.mag. i filosofi fra Københavns Universitet og BA i idehistorie og antropologi/etnografi fra Aarhus Universitet

\title{
GÖRANADAMSON: Svensk mångfaldspolitik - en kritik från vänster. Malmö: Arx förlag 2014. 181 sider. ISBN 978-91-87043-22-2. Pris: 163,00 SEK
}

Göran Adamson har skrevet en både tankevækkende, skræmmende og anbefalelsesværdig bog om det, man polemisk kan kalde multikulturalismens bløde totalitarisme. Bogen analyserer den officielle svenske policy, der søger at fremme etnisk mangfoldighed blandt offentligt ansatte, så mangfoldighed kommer til at fremstå som „en naturlig och integrerad del i myndigheters verksamhet“ (s. 13, se også s. 19). Det er et normativt mål, at samfundet ikke bare er, men også skal fungere ,mångkulturellt, vilket innebär att mångfald bejakas, främlingsfientlighet bekämpas och ersätts av ökad kulturell förståelse“, som Adamson (s. 75) citerer fra udredningen Mångfald i högskolan. Denne policy bliver introduceret af den socialdemokratiske regering i 1999, året efter udmøntes den i omtalte udredning, og op gennem det nye årtusinde bliver mangfoldighed etableret som norm for flere og flere offentlige institutioner og politiske partier.

Der er flere temaer i bogen, og da det ikke er muligt at komme ind på dem alle, har jeg valgt nogle enkelte nedslag. Adamsons bog er først og fremmest en undersøgelse af, hvordan offentlige myndigheder har gennemført policyen om mangfoldighed inden for de højere uddannelser („högskolan“) uden om den offentlige politiske opinion. Det er denne ovenfra ned-dikterede form for 
administrativ politisk og ideologisk styring, der er bogens emne, og det centrale spørgsmål drejer sig om, hvorvidt det leder til et mindre racistisk og et mere lige samfund, der er ledetråden for en venstrefløjspolitik. Det leder over i det andet tema, der fremgår af bogens undertitel, nemlig, at der er tale om en venstrefløjskritik. Det kan forekomme paradoksalt al den stund, både højre- og venstrefløj ser multikulturalisme som venstreorienteret. Men det er Adamsons centrale påstand, der lanceres på første linje i forordet, at det ikke er tilfældet: „Multikulturalism er en konservativ idé som tas för progressiv" (s. 11).

Man kan sige, at disse to temaer bindes sammen af en slags styringsmentalitet (jf. Foucault), der ser på, hvordan mangfoldighedspolicyen udmøntes, og hvordan den omdefinerer venstreorientering. I første omgang kan man hæfte sig ved, at centrale dokumenter er offentlige udredninger, at det er en norm for offentlig virksomhed, at den gennemføres pr. direktiv, og at der i øvrigt ikke gives belæg for, at mangfoldighedsnormen øger kvalitet og lighed, selv om det gentages i det uendelige. Det er bemærkelsesværdigt, at denne form for styring har opereret under partipolitikken og den offentlige opinions radar. Det hænger sammen med, at den er undfanget andetsteds og fungerer anderledes: Den er et politisk mantra blandt Socialdemokratiets spidser, den er blevet til som en administrativ diskurs af og for bureaukrater, og den bliver markedsført som en humanistisk diskurs tilsat globaliserings- og legitimationsimperativer. Disse fordrer, at Sverige kommer til at fremstå som en del af verden (s. 22), at uddannelsesinstitutionerne etnisk set afspejler samfundet (s. 45-8), og at man udviser tolerance over for etniske minoriteter.

Det, man ser her, illustrerer den form for eliteinduceret politisk kultur, der i så udpræget grad præger Sverige, og som har forkrøblet offentlig debat om integration af etniske minoriteter. Adamson stiller sig kritisk over for, at politik bliver udgrænset til fordel for påstande, hvis sandhedsværdi man ikke kan diskutere - såsom at mangfoldighed og kvalitet gensidigt betinger hinanden, hvilket analyseres i andet og tredje kapitel - og hvis moralske pænhed det er illegitimt at problematisere. Her er der klare paralleller til to danske udgivelser fra 2013, der også hudfletter udokumenterede sandheder og offentlig moraliseren: Mehmet Necef og Henning Bechs Er danskerne racister? og Stjernfelt og Eriksens De anstcendige. Spørgsmålet om racisme er sigende, ikke mindst fordi det fremstilles som den diametrale modsætning til mangfoldighed. Det indvarsler en kortslutning af politiske diskussioner, fordi kritik af sidstnævnte kan tages til indtægt for førstnævnte. Dertil kommer, at racisme ,innebär att hysa negativa eller 'fientliga' attityder mot främlingar”, hvorfor det bliver „svårt att skilja en allmän kritik mot främlingar från rasism i fascistisk och nazistisk mening" (s. 76). Konsekvenserne af dette er, at dem, der udtaler sig kritisk i offentligheden om forhold blandt etniske minoriteter, bliver tiet ihjel og/eller skudt racistiske motiver i skoene. 
Det andet punkt om styringsmentalitet vedrører, hvordan denne form for styring, der formuleres i teknokratiske og humanistiske termer, dels omdefinerer venstreorientering og dels undergraver demokratisk offentlighed. Som Adamson gør opmærksom på, sker dette i forbindelse med flere skift. Når det drejer sig om aktører, skifter fokus fra klasse til etnicitet, på trods af at klasse er udslagsgivende med hensyn til, om man vælger at studere videre (s. 57). Dette går hånd $\mathrm{i}$ hånd med en kulturalisering af politik, der har flere konsekvenser: Det flytter det demokratiske tyngdepunkt væk fra majoriteten og over på minoriteter, og det ændrer venstrefløjens lighedsfordring fra omfordeling og lige rettigheder til ligestilling mellem etniske grupper. Begge er forhold, der trækker i retning af gruppetænkning og segmentering af en demokratisk politisk offentlighed. Når majoritetskulturen i tilgift stemples som nationalistisk, konform og undertrykkende, vil det fremmedgøre ,almindelige mennesker“, der for en stor dels vedkommende har udgjort Socialdemokratiets kernevælgere. Det sidste har især været tydeligt i en dansk sammenhæng, hvor Dansk Folkeparti har gjort et stort indhug i det socialdemokratiske vælgerkorps. Endelig kan man i forlængelse heraf tilføje, at det demokratiske princip, at politik er for amatører, bliver erstattet af professionelles ekspertviden udi identitet og moral. Dette øger selvsagt afstanden mellem establishment og befolkning, samtidig med at det underminerer en åben demokratisk politisk kultur.

Lad mig afslutningsvis knytte nogle kommentarer til, hvad der efter Adamsons opfattelse står på spil med ,mångfald“" som en norm for videregående uddannelser (s. 152-54). For det første er universiteternes selvstændighed og dermed også den frie forskning truet af godhedsindustriens ideologiske propaganda. For det andet gør den ideologiske spændetrøje vold på det klassiske dannelsesideal, der er truet af den kundskabsfjendtlige mangfoldighedsdiskurs. For det tredje er de studerendes selvstændighed som individer truet af denne diskurs' kollektivistiske syn på dem som eksponenter for deres kultur.

Det er ikke alene offentlige institutioner og videregående uddannelser, der er truet, det er i høj grad også den politiske kultur og ytringsfrihed i særdeleshed. Her er det altoverskyggende problem, ,,att mångfalden är något annat än vi tror“: Det skulle være emanciperende, men det „förvandlar individer till etnicitetens fångar"; det skulle være moderne, „,men det bidrar till religionens återkomst“; det skulle skabe debat og være politisk, men „leder till censur“ og „trampar på allt politisk“" (s. 154).

Torben Bech Dyrberg

Cand.mag., ph.d., lektor

Institut for Samfund og Globalisering, RUC 